\title{
OPTIMISATION OF THE MUNICIPAL WASTE COLLECTION PROCESS IN A SMALL SIZE AND SCARCELY POPULATED MUNICIPALITY
}

\section{OPTYMALIZACJA PROCESU ODBIORU ODPADÓW KOMUNALNYCH W GMINIE MALEJ WIELKOŚCI I O MAŁEJ GĘSTOŚCI ZALUDNIENIA}

\author{
Mariusz Rychlicki, Zbigniew Kasprzyk, Konrad Jaśkiewicz
}

Warsaw University of Technology, Faculty of Transport Politechnika Warszawska, Wydział Transportu

\begin{abstract}
The paper presents a review of legal conditions regarding the process of municipal waste collection. An analysis of systems and solutions for the management and monitoring of a fleet of vehicles that can be used in the operation of means of transport during the implementation of the municipal waste process was carried out. The paper presents a coherent concept of ICT system for the optimization of the municipal waste collection process in a small-sized municipality. The proposed system can be used by companies responsible for waste collection, transport and service companies participating in the waste collection process. By basing the system on commonly available elements and services (Internet, GSM and GPS), its installation and operation is fast, simple and does not require large financial outlays.
\end{abstract}

Keywords: exploitation, optimization, receiving of waste

Streszczenie: $W$ pracy dokonano przegladu uwarunkowań prawnych, dotyczacych procesu odbioru odpadów komunalnych. Przeprowadzono analize systemów i rozwiazań stużacych zarzadzaniu i monitorowaniu floty pojazdów, które moga zostać wykorzystane w eksploatacji środków transportu podczas realizacji procesu odbioru odpadów komunalnych. Przedstawiona została spójna koncepcja teleinformatycznego systemu optymalizacji procesu odbioru odpadów komunalnych $w$ gminie małej wielkości. Zaproponowany system może zostać wykorzystany przez firmy odpowiedzialne za odbiór odpadów, przedsiębiorstwa transportowe i ustugowe, uczestniczace $w$ procesie odbioru odpadów. Poprzez oparcie systemu o powszechnie dostepne elementy $i$ ustugi (sieć Internet, GSM i GPS), jego instalacja $i$ eksploatacja jest szybka, prosta $i$ nie wymaga dużych naktadów finansowych.

Stowa kluczowe: eksploatacja, optymalizacja, odbiór odpadów 
Optimisation of the municipal waste collection process in a small size and...

Optymalizacja procesu odbioru odpadów komunalnych w gminie małej wielkości...

\section{OPTIMISATION OF THE MUNICIPAL WASTE COLLECTION PROCESS IN A SMALL SIZE AND SCARCELY POPULATED MUNICIPALITY}

\section{Introduction}

On 1 July 2013, the amended Act on maintaining cleanliness and order in municipalities was adopted. It diametrically changed the waste management system. Pursuant to the introduced Act, the control of waste and its collection was taken by local governments. Until the entry into force of the new law, there had been a lot of arbitrariness and insubordination in the waste collection and management market. It led to a number of irregularities and malpractices, such as the disposal of waste to forests or storage in places not intended for it. In addition to choosing a company, it became a new obligation of local governments to control the companies that receive waste and to impose penalties in the event of failure to comply with the provisions. Landfills and their compliance with the applicable law requirements are checked. Another obligation of the local governments is to inform the inhabitants of municipalities about the way of sorting and collection of waste.

The increase in quality requirements in relation to the organisation of the waste collection process obviously must have caused an increase in the costs of its implementation. It results in the resistance and reluctance of inhabitants, whom this cost is transferred to in the final settlement. Therefore, the elected local governments strive for the maximum reduction of these costs. It is facilitated by the selection of companies by way of a tender, where a price is still the main decisionmaking parameter. However, for transport companies, it is an extremely unfavourable situation because it mainly competes in the field of transport costs and not their quality. Thus, the transport companies, which implement the waste collection process, are forced to search for solutions that allow to reduce the costs and optimise the use of transport means. It is supported by ICT solutions used for location and monitoring of vehicles, as well as efficient communication, both with employees and inhabitants.

\section{Legal and organisational requirements for the waste collection process}

The unambiguous definition of the "waste" term is not an easy operation, because the final content of this definition is largely determined by a number of factors. In the Polish Scientific Publisher's Encyclopaedia [Encyklopedia Popularna PWN] of 1982, the following explanation can be found under the "waste" term: a product that does not apply to the production of a given plant [1]. This definition is far narrowed, because according to it, waste is only a derivative of the production process implementation, and it completely ignores the social aspect of waste generation. 
A more detailed definition was developed in 1997 and its content is included in the Universal Encyclopaedia [Encyklopedia Powszechna]. According to it, the waste includes "by-products of the human activity, unsuitable in the place and time in which they were created, harmful or burdensome to the natural environment" [2]. The definition included in the Act on waste stipulates that the waste is "any substance or object belonging to one of the categories (...), which the owner disposes of, intends to get rid of or it is required to its disposal" [3].

Any unused and unspecified product acquires the properties of waste. Each waste becomes a raw material or a material, when it is used. Thus, each matter acquired, processed and moved by a human can be a resource and a useful product or waste with a different nuisance to the environment. It all depends on what a human will do with a given matter.

The activities causing or likely to cause the waste generation should be planned, designed and conducted as to meet the requirements of the waste management regulations. Above all, these activities should take into account the prevention of waste generation or at least the reduction of waste. A negative impact on the environment during the manufacture and use of products should also be under control. In a situation of failure to avoid waste generation, the activities should be planned in such a way that they ensure the recovery consistent with the environmental protection regulations. However, in a situation when the recovery of the generated waste is impossible, it is necessary to ensure their neutralisation in accordance with the environmental protection regulations [4].

\section{ICT systems in the operation of means of transport}

The vehicle monitoring systems, based on the use of the GPS system, have gained popularity and they have been increasingly popular since the time of making them available for wider use. The idea of this system is based on the use of information from satellites placed in orbits around the Earth. Owing to the receipt and processing of this piece of information, it is possible to determine the exact position (accuracy depends on the number of visible satellites), as well as to specify the speed of the vehicle movement. In general, the principle of operation of all satellite navigation systems is based on a structure composed of 3 basic segments: space, ground and users [5], which cooperate with each other in obtaining and exchanging information. The communication and exchange of information between the vehicles and the panel is ensured by GSM technology (Global System for Mobile Communications), which is a standard for mobile telephony that allows for voice, data and message transmission. It is based on radio communication between the terminal and base stations and system control panels [6]. The data transmission in the GSM system is enabled by GPRS technology (General Packet Radio Service), which is commonly used. In less advanced applications, from the perspective of transmission, the use of an older and simpler communication technique with the use of text messages is not excluded [7]. 
Optimisation of the municipal waste collection process in a small size and... Optymalizacja procesu odbioru odpadów komunalnych w gminie małej wielkości...

The efficient and effective use of read data and the implementation of the abovementioned functions will allow not only for effective and reliable implementation of the transport process but also for optimisation of the costs of transport and operation of vehicles. It is particularly important in the discussed case, where the transport companies have to compete mainly in the field of the price of the provided service. At the same time, it takes place under conditions of very strict control and rigorous requirements regarding reliability and timeliness of the implementation of the municipal waste collection and transport services.

\section{Possibilities of information exchange in remote vehicle supervision systems}

In the solutions based on the exchange and processing of information, the ITC information systems take up a significant and well-established position. Their flexibility and universality allow for easy implementation at the systemic level and almost unlimited application possibilities. It is facilitated by a fairly technologically simple hardware base and access to the system software with extensive configuration options. Currently, the use of GPRS data transmission in this scope is common. However, when one of the elements of the system is communication with inhabitants, this solution has some drawbacks, mainly in the necessity of using the dedicated software in terminals (telephones) of end users (inhabitants of the municipality). It is worth noting that in such a solution there is no problem of operation in real time or too much data to send. On the contrary, the sent messages should be simple and concise. The use of classic SMS services seems to be sufficient here, which gives a complete system solution for exchanging information based on a question-answer formula.

The practical implementation of such system solutions will require solving a number of issues. One of them includes the issues of the system efficiency, that is its ability to process the assumed number of information and questions within a certain time interval. The measure of the system efficiency understood in such a way can be an activity rate [8]. The solutions of this type require the dedicated system software with the maximum extensive configuration options. This condition is met by, e.g. ActiveXperts SMS Messaging Server software, which is the software of a framework type [7]. It is dedicated to sending, receiving and processing text and e-mail messages, as well as creating own applications using these functions and mechanisms. Along with the hardware base (server, GSM modems) and access to databases, this software allows to create information systems that easily implement various information functions, e.g. of the question-answer type.

In order to properly carry out the process of sending the text messages, a simple hardware infrastructure, adjusted to it, is needed. The GSM modem should be connected to a computer with the installed ActiveXperts SMS Messaging Server programme via USB or COM port, and a SIM card should be inserted in it. The software allows to send up to 10 text messages per minute, which are then stored in the databases of the programmes, such as: Microsoft SQL Server (MS SQL), MySQL, Microsoft Access. 
The system performance increase can be easily achieved by increasing the number of GSM modems. However, the question arises whether such a system will perform its task correctly, maintaining its readiness at a satisfactory level, not only due to technical reliability, but also efficiency?

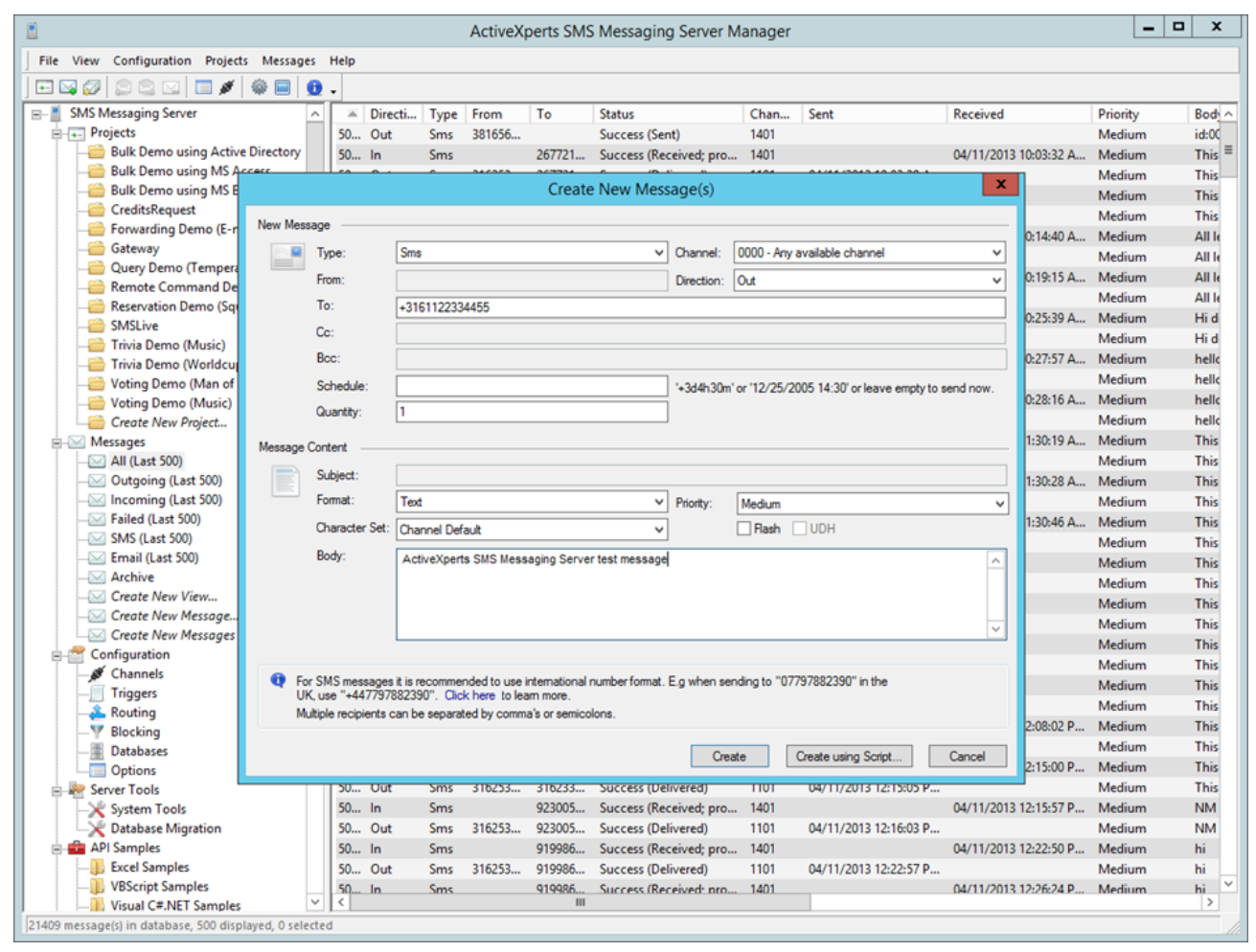

Fig. 1 Window for creating a new SMS/e-mail in the Active Xperts SMS Messaging Server programme [7]

The discussed system is ideologically very similar to the general central server model. It is comprehensively and very well described in the literature $[10,11]$, as well as supported by numerous examples. The analysed information system consists of the SMS server, which is the S1 central unit, the operation of which is controlled by the P1 processor. The GSM modems, which constitute the Si input/output units, which admittedly have less utility computing, but they are also controlled by own processors $\mathrm{Pi}(\mathrm{i}=2,3, \ldots, \mathrm{M})$, are connected to the server. The modems receive notifications (text messages), which are sent to the server for processing. The server performs the reception of text messages, handles the database, formats the response for sending the feedback (response) and sends it to one of the GSM modems. In addition, the server and the P1 processor must perform the tasks of the operating system and access to the database, which means that they must have a reserve of power and time for their implementation. 
Optimisation of the municipal waste collection process in a small size and...

Optymalizacja procesu odbioru odpadów komunalnych w gminie małej wielkości...

Such an approach allows to treat the analysed information system as a generalised model of a closed exponential network, the diagram of which is shown in Figure 2.

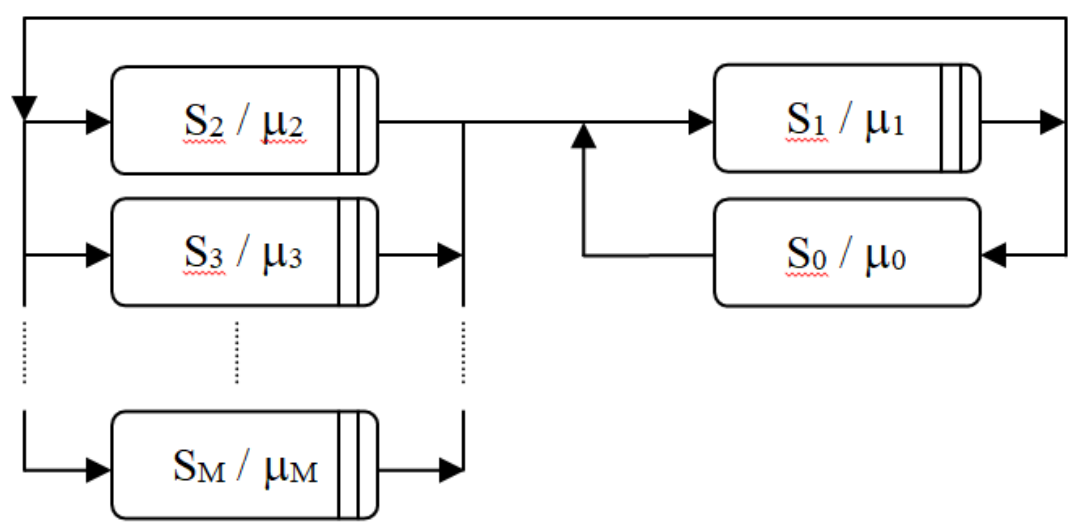

Fig. 2 Diagram of a generalised model of the ICT system [8]

The handling times of the text messages implemented by the Pi processors of each modem are statistically independent of each other, and they are subject to the $\mu \mathrm{i}$ exponential distribution. The rigour of servicing the text message queue is the FIFO discipline. The server deals with handling each text message for a specified period of time, after which it generates a response with the pi probability to the modem and it proceeds to handle the next text message. We assume the average handling time marking

$$
\frac{1}{\mu_{i}}, \text { dla } \mathrm{i}=1, \ldots ., \mathrm{M}
$$

and we determine the activity indicator of the i modem Ui $(0 \leq \mathrm{Ui} \leq 1)$, which determines in which part of the analysed time interval the modem is busy with handling the incoming text messages. According to the Chang-Lavenberg theorem [11], the activity indicator of the i modem:

$$
U_{i}=\rho_{i}, \text { dla } \mathrm{i}=1, \ldots ., \mathrm{M}
$$

The previous papers [9] presented the measurement parameters obtained during the tests of the developed information system, based on the SMS service. Their purpose was to determine the time necessary to handle a certain number of text messages using the standard GSM modems. The measurement results of the times of sending the text messages did not show any significant differences, neither depending on the number of text messages in a one-off package (sent SMS portion), nor depending on the used GSM network. Only in case of one network, there was a noticeable increase in the time of sending text messages depending on the number of text messages in the package. In this network, there was also the loss of order in the delivered text messages (each text message had a unique identifier), which was not observed while sending in other networks. 
There were no significant differences in relation to the used GSM modem or the applied software. The paper [8] presents a detailed analysis and the measurement and simulation results of the ICT system model, which uses the text messages, developed in order to increase the efficiency of information systems. It was shown that the increase in the readiness of such a system is possible owing to the even load of each of the GSM modems. It allows for a double increase in the number of text messages to be processed, which contributes to a double increase in the efficiency of the information system.

\section{Operation of vehicles in the municipal waste collection system on the example of the small municipality}

For the needs of the analysis, the municipality of Paradyż was selected, which is a rural municipality located in the southern part of the Mazovian Lowland, at the Czarna river, in the water catchment area of Pilica river, in the south-eastern part of Lódź Province, in the Opoczno County. It covers the area of $81.4 \mathrm{~km} 2$, consists of 27 villages and it is inhabited by 4458 inhabitants [12].

On the basis of the carried out community interview and discussions with the authorities of the Paradyż municipality, it was found that there are several problematic issues of waste collection from the inhabitants. One of the problems was the collection of waste in the town of Kłopotów. A part of the village is located on the main national road and it is connected with Piotrkowska Street in Paradyż. The collection of sorted waste took place in odd months, while in Paradyż in even months. The inhabitants left the waste in even and odd

months, claiming that the company receives the sorted waste from them (Paradyż municipality was divided into two regions. Mixed waste is collected once a month in the entire municipality, and sorted waste is collected every second month). Therefore, there was a problem reported by the inhabitants whether the collection is in a given month or the next one. The inhabitants left the waste in both months, claiming that the company receives the sorted waste from them, and it only involved mixed waste, therefore, the problem was reported by the inhabitants, whether the collection is in a given month or the next one.

Another problem includes the properties in Adamów, Przyłęk, Solec, Stanisławów and Sylwerynów, the access to which is hindered due to unpaved road surfaces. Therefore, the collection of waste from these properties had to be carried out by a vehicle with a lower load capacity, which generated additional costs. The Waste Treatment Plant is located in Różana, more than $20 \mathrm{~km}$ away from Paradyż. Some of the property owners also reported a need for more frequent collection of selective waste than every second month, as it is currently.

In order to improve the entire process and obtain the optimum parameters of using the means of transport participating in the process, a solution based on the SMS notification system was proposed. With its help, the inhabitants report a need for the service. In case of collecting its appropriate number, the programme provides a notification to the company responsible for collecting waste, which sends the vehicle, adapted to the appropriate service (due to the number of notifications or the notifications from the property owners, for whom there is difficult access). 
Optimisation of the municipal waste collection process in a small size and...

Optymalizacja procesu odbioru odpadów komunalnych w gminie małej wielkości...

Another task of the created system is to inform all the inhabitants in advance about the planned collection of mixed and selective waste from the properties.

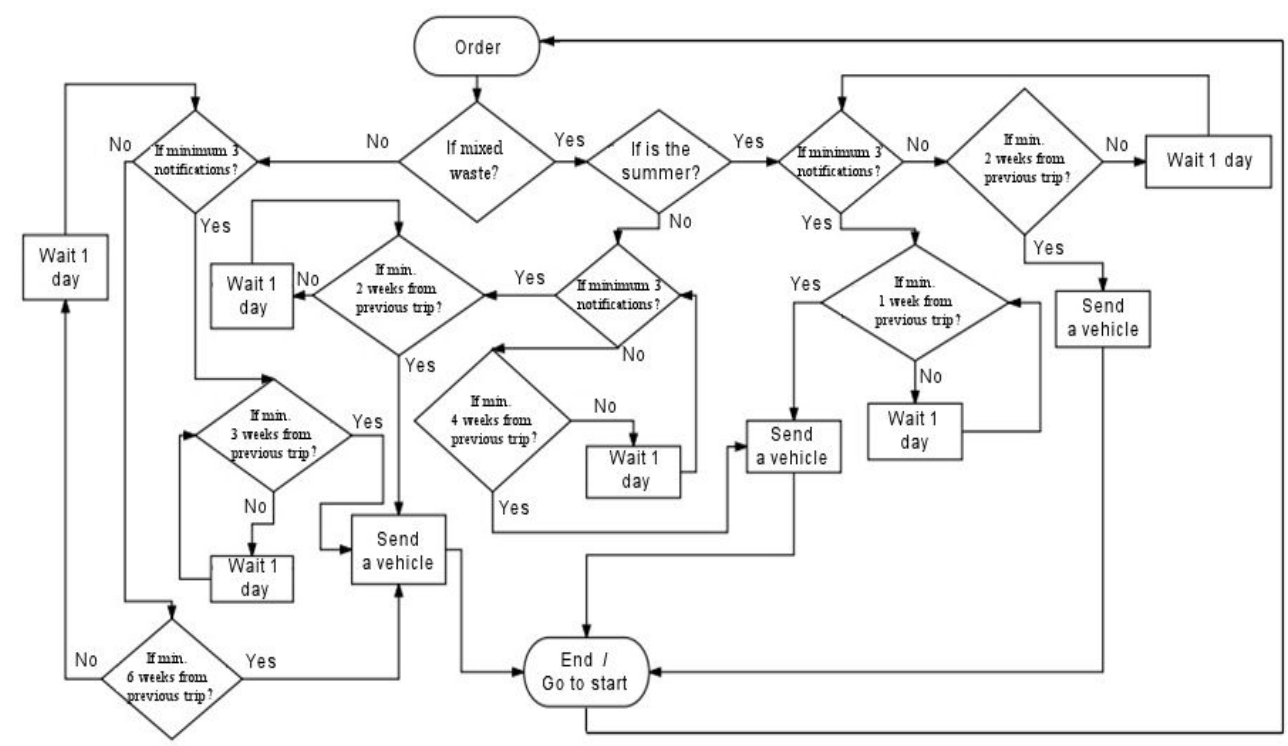

Fig. 3 Algorithm of operation of the waste collection process system [13]

The functioning of the waste collection system is presented with the use of an algorithm. Due to the climate and prevailing weather conditions in Poland, the calendar year was divided into two periods, where the main difference between these periods is the frequency of waste collection: summer (from 1 May to 30 September) and winter (from 1 October to 30 April).

After familiarising with the waste collection requirements and for the needs of the algorithm, the following criteria were determined due to the type of waste, the date of its collection and the profitability of the round trips.

mixed waste: minimum 3 notifications; minimum 1 week from the previous trip in the summer; maximum 2 weeks from the previous trip in the summer; minimum 2 weeks from the previous trip in the winter; maximum 4 weeks from the previous trip in the winter.

selective waste: minimum 3 notifications; minimum 3 weeks from the previous trip; maximum 6 weeks from the previous trip.

The system software notifies in advance all the system users (inhabitants) about the planned trip of the vehicle in order to collect waste. The next collection will be possible after the minimum time specified in the algorithm for a given type of notification. 


\section{Conclusion}

The developed solution is dedicated to small municipalities, where due to the relatively small number of inhabitants, the planning and organization of transport waste collection, is of particular importance. This problem is becoming even more important in scarcely populated areas, where the proportionally small number of collection points is spread over a relatively large area. It is the main reason for the increase in transport costs generated by passing in only partial use of the capacity of vehicles. It contributes to a significant increase in the operating costs of the maintained fleet of vehicles. In the situation of the implementation of transport within the dedicated act and the contract concluded with the local government regulating the frequency and timeliness of the waste collection, there is no simple mechanism that guarantees the reduction of costs to the acceptable level.

The proposed and analysed solution faces these problems and greatly contributes to the optimisation of transport costs and the increase in the efficiency of the operation of the means of transport. The developed and tested application increases the entire system readiness, understood as timely implementation of the task while minimising the operating costs. At the same time, it is possible to scale the system and implement it in the conditions of significant demographic and area differences. When developing and using the simulation model in the further research, it will be possible to determine the reliability indicators, which will enable to develop the guidelines that allow for the implementation of the developed solution in practice.

The article was prepared within the framework of the project RID 4D „Impact of services of Intelligent Transport Systems on the level of road safety", funded by the National Centre for Research and Development and the Directorate for National Roads and Motorways (Contract No. DZP/RID-I-41/7/NCBR/2016).

\section{Bibliography}

[1] Encyklopedia Popularna PWN - wydanie szóste, Państwowe Wydawnictwo Naukowe, Warszawa 1982;

[2] Encyklopedia Powszechna PWN - tom 4, Wydawnictwo Naukowe PWN, Warszawa 1997;

[3] Ustawa z dnia 27 kwietnia 2007 r. Prawo ochrony środowiska [Dz. U. Nr 42, poz. 328.];

[4] Radecki W., Ustawa o odpadach, Wolters Kluwer Polska, Warszawa 2008;

[5] Narkiewicz J.: GPS i inne satelitarne systemy nawigacyjne, Wydawnictwo Komunikacji i Łączności, Warszawa 2007;

[6] Maciejewski M., Waleriańczyk W.: Porównanie systemów monitorowania i nawigacji dla floty pojazdów dostępnych na polskim rynku, VII konferencja naukowo-techniczna, Logistyka, Lidzbark Warmiński 2014;

[7] Product catalogue, http://www.activexperts.com/sms-messaging-server/, grudzień 2017; 
Optimisation of the municipal waste collection process in a small size and...

Optymalizacja procesu odbioru odpadów komunalnych w gminie małej wielkości...

[8] Rychlicki M., Kasprzyk Z.: Increasing Performance of SMS Based Information Systems, Advances in Intelligent Systems and Computing, vol. 286, 2014, Springer International Publishing, ISBN 978-3-319-07012-4;

[9] Rychlicki M., Kasprzyk Z., Integracja usług poczty elektronicznej oraz sms w małych i średnich przedsiębiorstwach transportowych, Zeszyty Naukowe Politechniki Warszawskiej, Seria Transport, z. nr 92, 1230-9265, Oficyna Wydawnicza Politechniki Warszawskiej 2013,

[10] Czachórski T., Modele kolejkowe systemów komputerowych, Politechnika Śląska, Gliwice 1999,

[11] Filipowicz B., Modele stochastyczne w badaniach operacyjnych - analiza i synteza systemów obsługi i sieci kolejkowych, , WNT, Warszawa 1996.

[12] Główny Urząd Statystyczny: Ludność w gminach według stanu w dniu 31.12.2011 r. Bilans opracowany w oparciu o wyniki Narodowego Spisu Powszechnego 2011; dostępny na stronie: http://demografia.stat.gov.pl

[13] Jaśkiewicz K.: Projekt systemu monitorowania pojazdów i odbioru odpadów na przykładzie małej gminy, praca dyplomowa inżynierska, WT PW, Warszawa 2017;

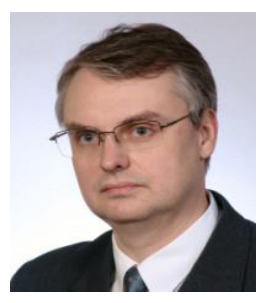

Mariusz Rychlicki, Ph.D., Assistant Professor, Department of Transport, Warsaw University of Technology. Research interests: modeling of telematics systems, analysis of localization monitoring and systems, reliability analysis of data communication networks. Author of dozens of scientific-technical articles (Share 30\%).

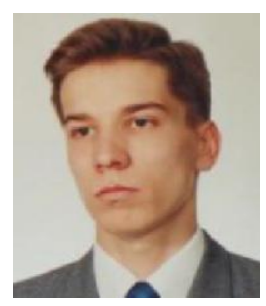

Zbigniew Kasprzyk, Ph.D., Assistant Professor, Department of Transport, Warsaw University of Technology. Research interests: modeling of toll systems, modeling of the functions of transport telematics equipment, analysis of operating systems, reliability analysis of data communication networks. Author of dozens of scientific-technical articles (Share 30\%).

Konrad Jaśkiewicz, Eng., graduate of Department of Transport, Warsaw University of Technology. Professional interests: Intelligent transportation systems, localization and vehicles tracking systems (Share 40\%). 


\section{OPTYMALIZACJA PROCESU ODBIORU ODPADÓW KOMUNALNYCH W GMINIE MALEJ WIELKOŚCI I O MALEJ GECTOŚCI ZALUDNIENIA}

\section{Wstęp}

W dniu 1 lipca 2013 roku wprowadzono znowelizowaną ustawę o utrzymaniu czystości i porządku $w$ gminach. Zmieniła ona diametralnie system gospodarowania odpadami. Na mocy wprowadzonej ustawy kontrolę nad odpadami i ich odbiorem przejęły samorządy. Do czasu wejścia w życie nowej ustawy na rynku odbioru i zagospodarowania odpadów panowała duża samowola i niesubordynacja. Prowadziło to do szeregu nieprawidłowości i nadużyć, jak wywóz odpadów do lasów lub składowanie w miejscach do tego nieprzeznaczonych. Oprócz wyboru przedsiębiorstwa, nowym obowiązkiem samorządów stało się kontrolowanie firm przyjmujących odpady oraz nakładanie kar w przypadku braku stosowania się do wprowadzonych przepisów. Sprawdzane są składowiska odpadów i ich zgodność z wymogami obowiązującego prawa. Kolejnym obowiązkiem samorządów jest informowanie mieszkańców gmin o sposobie sortowania i odbioru odpadów.

Wzrost wymagań jakościowych $\mathrm{w}$ odniesieniu do organizacji procesu odbioru odpadów w oczywisty sposób musiał spowodować wzrost kosztów jego realizacji. Budzi to opór i niechęć mieszkańców, na których w ostatecznym rozrachunku ten koszt jest przenoszony. $\mathrm{Z}$ tego powodu władze samorządowe, pochodzące $\mathrm{z}$ wyboru, dążą do maksymalnej redukcji tych kosztów. Sprzyja temu wybór firm w drodze przetargu, gdzie nadal głównym parametrem decyzyjnym jest cena. Dla firm transportowych jest to jednak wyjątkowo niekorzystna sytuacja, gdyż prowadzi ona konkurowania głownie na polu kosztów przewozów a nie ich jakości. Tym samym firmy transportowe realizujące proces odbioru odpadów zmuszane są do poszukiwań rozwiązań umożliwiających redukcję kosztów i optymalizację wykorzystania środków transportu. Sprzyjają temu rozwiązania teleinformatyczne, służące do lokalizacji i monitorowania pojazdów oraz sprawnej komunikacji, zarówno z pracownikami, jak i mieszkańcami.

\section{Wymagania prawne i organizacyjne dla procesu odbioru odpadów}

Jednoznaczne zdefiniowanie pojęcia „odpad” nie jest działaniem łatwym, albowiem ostateczna treść tejże definicji w znacznej mierze uwarunkowana jest szeregiem czynników. W Encyklopedii Popularnej PWN z 1982 roku pod pojęciem „odpad” odnaleźć można następujące objaśnienie: produkt, który nie ma zastosowania w produkcji danego zakładu [1]. Definicja ta jest dalece zawężona, albowiem zgodnie z nią odpady są pochodną tylko i wyłącznie realizacji procesu produkcyjnego. $\mathrm{w}$ zupełności pomija ona aspekt społeczny generowania odpadów. Bardziej szczegółowa definicja opracowana została w roku 1997 a jej treść zawarto w Encyklopedii Powszechnej. 
Optimisation of the municipal waste collection process in a small size and... Optymalizacja procesu odbioru odpadów komunalnych w gminie małej wielkości...

Zgodnie z nią, odpady to "uboczne produkty działalności człowieka, nieprzydatne w miejscu i czasie, w którym powstały, szkodliwe lub uciążliwe dla środowiska przyrodniczego" [2]. Definicja zawarta w ustawie o odpadach stanowi, iż odpad to "każda substancja lub przedmiot należący do jednej z kategorii (...), których posiadać pozbywa się, zamierza się pozbyć lub do ich pozbycia się jest zobowiązany" [3].

Każdy niezagospodarowany i nie mający określonego przeznaczenia produkt nabywa właściwości odpadu. Każdy odpad staje się surowcem lub materiałem z chwilą jego zagospodarowania. Każda zatem materia pozyskiwana, przetwarzana i przemieszczana przez człowieka może być zasobem i produktem użytecznym lub odpadem o różnej uciążliwości dla otoczenia. Wszystko zależy od tego, co z daną materią uczyni człowiek.

Działania powodujące lub mogące powodować powstawanie odpadów powinny być planowane, projektowane i prowadzone tak, aby spełniały wymogi zasad gospodarowania odpadami. Przede wszystkim działania te powinny uwzględniać zapobieganie powstawaniu odpadów lub przynajmniej ograniczanie ich ilości. Również negatywne oddziaływanie na środowisko podczas wytwarzania i użytkowania produktów należy mieć pod kontrolą. W sytuacji, kiedy nie udaje się uniknąć powstawania odpadów, działania należy zaplanować w taki sposób, aby zapewniały one zgodny $\mathrm{z}$ zasadami ochrony środowiska odzysk. Natomiast w sytuacji, kiedy odzysk powstałych odpadów jest niemożliwy, należy zapewnić zgodne z zasadami ochrony środowiska ich unieszkodliwianie [4].

\section{Systemy teleinformatyczne w eksploatacji środków transportu}

Od czasu udostępnienia do szerszego wykorzystania bardzo szybko w transporcie drogowym zdobyły popularność i cieszą się coraz większym zainteresowaniem systemy monitoringu pojazdów bazujące na wykorzystaniu systemu GPS. Idea tego systemu opiera się na wykorzystaniu informacji pochodzących $\mathrm{z}$ satelitów umieszczonych na orbitach wokół Ziemi. Dzięki odbiorowi i przetworzeniu tej informacji możliwe jest wyznaczenie dokładnej pozycji (dokładność jest zależna od liczby widocznych satelitów) a także określenie prędkości poruszania się pojazdu. Generalnie zasada działania wszystkich systemów nawigacji satelitarnej opiera się na strukturze złożonej z 3 podstawowych segmentów: kosmicznego, naziemnego i użytkowników [5], które współpracują ze sobą przy pozyskiwaniu i wymianie informacji. Samą łączność i wymianę informacji pomiędzy pojazdami a centralą zapewnia technologia GSM (ang. Global System for Mobile Communications), która jest standardem telefonii komórkowej, umożliwiającym transmisję głosu, danych i wiadomości. Opiera się on na komunikacji radiowej pomiędzy terminalem a stacjami bazowymi i centralami systemu [6]. Transmisję danych w systemie GSM umożliwia technika GPRS (ang. General Packet Radio Service), która jest powszechnie wykorzystywana. W mniej zaawansowanych z punktu widzenia transmisji zastosowaniach nie wykluczone jest wykorzystanie starszej i prostszej techniki komunikacji za pomocą wiadomości SMS [7]. 
Sprawne i efektywne wykorzystanie odczytywanych danych oraz realizacja ww. funkcji umożliwiają nie tylko efektywną i niezawodną realizację procesu transportowego, lecz także optymalizację kosztów przewozu i eksploatacji pojazdów. Jest to szczególnie istotne w omawianym przypadku, gdzie firmom przewozowym przychodzi konkurować głównie na polu ceny świadczonej usługi. Jednocześnie odbywa się to w warunkach bardzo ścisłej kontroli i rygorystycznych wymagań odnośnie niezawodności i terminowości realizacji usługi odbioru i przewozu odpadów komunalnych.

\section{Możliwości wymiany informacji w systemach zdalnego nadzoru nad pojazdami}

$\mathrm{W}$ rozwiązaniach opartych na wymianie i przetwarzaniu informacji teleinformatyczne systemy informacyjne zajmują znaczącą i ugruntowaną pozycję. Ich elastyczność i uniwersalność pozwala na łatwą implementację na poziomie systemowym i wręcz nieograniczone możliwości zastosowań. Sprzyja temu dość prosta technologicznie baza sprzętowa oraz dostęp do oprogramowania systemowego o rozbudowanych możliwościach konfiguracyjnych. Obecnie powszechne jest wykorzystanie w tym zakresie transmisji danych GPRS. W przypadku jednak, kiedy jednym z elementów systemu jest komunikacja z mieszkańcami to rozwiązanie ma pewne wady, głównie w zakresie konieczności stosowania dedykowanego oprogramowania w terminalach (telefonach) użytkowników końcowych (mieszkańców gminy). Warto zauważyć, że w takim rozwiązaniu nie występuje problem pracy w czasie rzeczywistym, ani zbyt duża liczba danych do przesłania. Przeciwnie, przesyłane komunikaty powinny być proste i zwięzłe. Wystarczające wydaje się tutaj wykorzystanie klasycznych usług SMS, co daje kompletne, systemowe rozwiązanie służące wymianie informacji na zasadzie formuły pytanie-odpowiedź.

Praktyczna implementacja takich rozwiązań systemowych wymagać będzie rozwiązania szeregu zagadnień. Jednym z nich są kwestie wydajności systemu, czyli jego zdolności do przetworzenia założonej liczby informacji oraz zapytań w określonym przedziale czasowym. Miarą tak rozumianej wydajności systemowej może być wskaźnik aktywności [8]. Rozwiązania tego typu wymagają dedykowanego oprogramowania systemowego o maksymalnie rozbudowanych możliwościach konfiguracyjnych. Warunek taki spełnia np. oprogramowanie ActiveXperts SMS Messaging Server, będące oprogramowaniem typu framework [7]. Jest ono dedykowane wysyłaniu, odbieraniu oraz przetwarzaniu wiadomości SMS i e-mail, a także tworzeniu własnych aplikacji wykorzystujących te funkcje i mechanizmy. Razem z bazą sprzętową (serwer, modemy GSM) i dostępem do baz danych oprogramowanie to pozwala na tworzenie systemów informacyjnych, w prosty sposób realizujących różnorodne funkcje informacyjne np. typu pytanieodpowiedź.

Do prawidłowego przeprowadzenia procesu wysyłania wiadomości SMS potrzeba prostej, dostosowanej do tego infrastruktury sprzętowej. 
Optimisation of the municipal waste collection process in a small size and...

Optymalizacja procesu odbioru odpadów komunalnych w gminie małej wielkości...

Do komputera z zainstalowanym programem ActiveXperts SMS Messaging Server należy podłączyć za pomocą portu USB lub COM, modem GSM oraz umiejscowić w nim kartę SIM. Oprogramowanie umożliwia wysyłanie do 10 wiadomości SMS w ciągu minuty, które następnie zapisywane są w bazach programów takich jak na przykład: Microsoft SQL Server (MS SQL), MySQL, Microsoft Access. Zwiększenie wydajności systemu można łatwo osiągnąć poprzez zwiększenie liczby modemów GSM. Pojawia się jednak pytanie, czy taki system będzie poprawnie realizować swoje zadanie, utrzymując swoją gotowość na zadowalającym poziomie nie tylko ze względu na niezawodność techniczną, ale również wydajność?

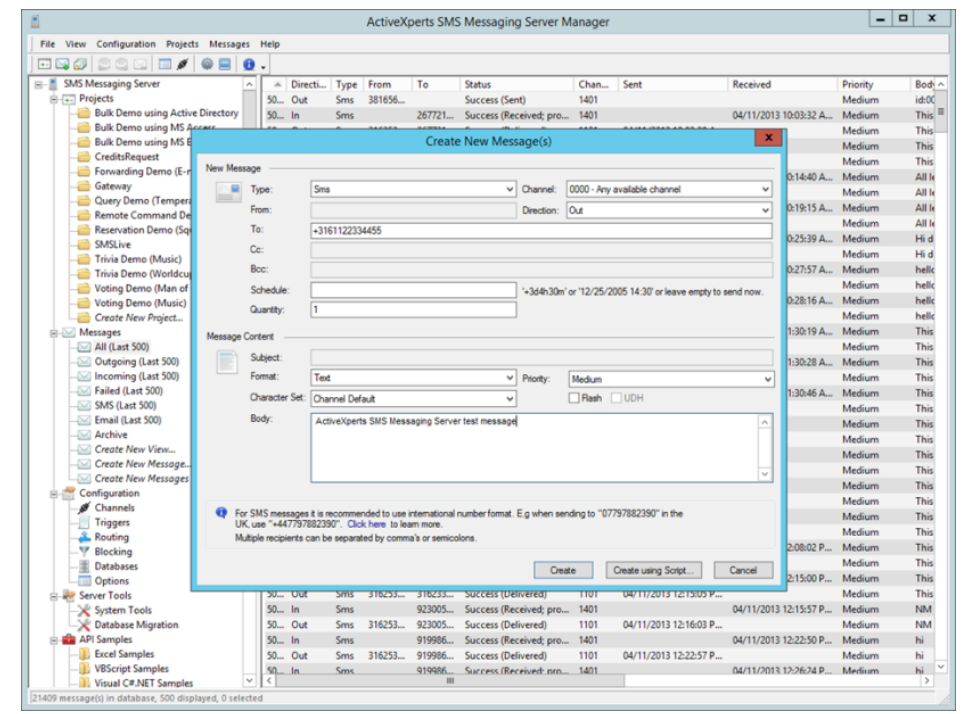

Rys. 1 Okno tworzenia nowej wiadomości SMS/e-mail w programie Active Xperts SMS Messaging Server [7]

Omawiany system jest ideowo bardzo zbliżony do ogólnego modelu serwera centralnego. Jest on wyczerpująco i bardzo dobrze opisany w literaturze $[10,11]$, a także poparty licznymi przykładami. Analizowany system informacyjny składa się z serwera SMS, będącego jednostką centralną $\mathrm{S}_{1}$, której pracą steruje procesor $\mathrm{P}_{1}$. Do serwera podłączone są modemy GSM, będące jednostkami wejścia/wyjścia $S_{\mathrm{i}}$ które, wprawdzie o znacznie mniejszej mocy obliczeniowej, ale także sterowane są własnymi procesorami $\mathrm{P}_{\mathrm{i}}(\mathrm{i}=2,3, \ldots, \mathrm{M})$. Do modemów napływają zgłoszenia (wiadomości SMS), które kierowane są do serwera w celu przetworzenia. Serwer realizuje odbiór wiadomości SMS, obsługuje bazę danych, formatuje odpowiedź do wysyłki informacji zwrotnej (odpowiedzi) i kieruje ją do jednego z modemów GSM. Dodatkowo serwer i procesor $\mathrm{P}_{1}$ muszą realizować zadania systemu operacyjnego i dostępu do bazy danych, co oznacza że muszą posiadać zapas mocy i czasu dla ich realizacji. 
Takie podejście pozwala potraktować analizowany system informacyjny jak uogólniony model sieci wykładniczej zamkniętej, której schemat został przedstawiony na rysunku 2 .

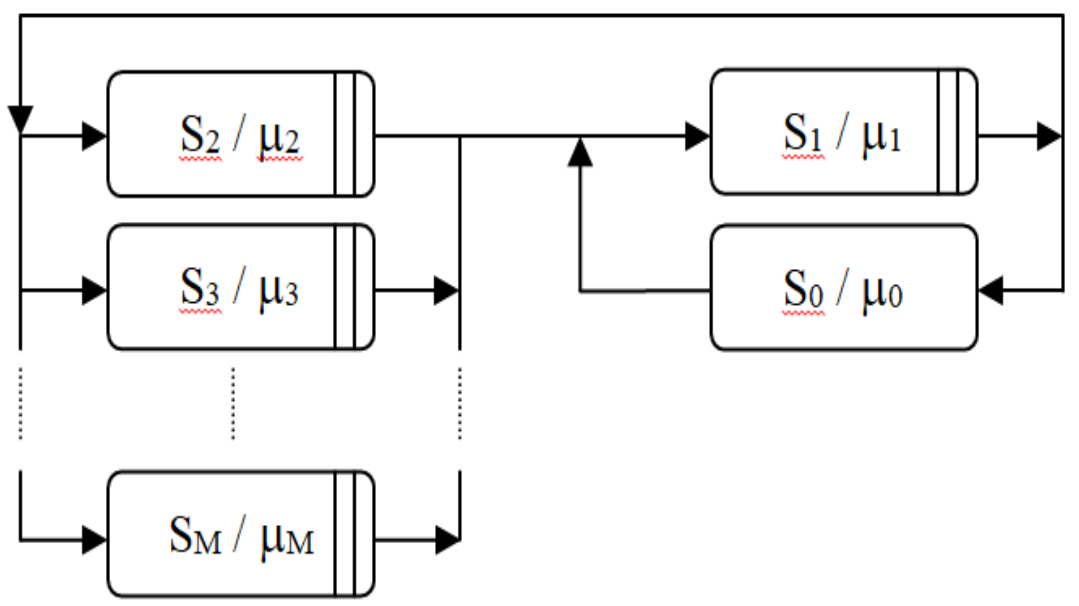

Rys. 2 Schemat uogólnionego modelu systemu teleinformatycznego [8]

Czasy obsługi wiadomości SMS realizowanych przez procesory $\mathrm{P}_{\mathrm{i}}$ każdego z modemów są niezależne statystycznie od siebie i podlegają rozkładowi wykładniczemu $\mu_{\mathrm{i}}$. Rygorem obsługi kolejki wiadomości SMS jest dyscyplina FIFO. Serwer zajmuje się obsługą każdej wiadomości SMS przez określony czas, po czym generuje do modemu odpowiedź z prawdopodobieństwem $\mathrm{p}_{\mathrm{i}}$ i przechodzi do obsługi kolejnej wiadomości SMS. Przyjmujemy oznaczenie średniego czasu obsługi

$$
\frac{1}{\mu_{i}} \text {, dla } \mathrm{i}=1, \ldots ., \mathrm{M}
$$

oraz określamy wskaźnik aktywności i-tego modemu Ui $(0 \leq \mathrm{Ui} \leq 1)$, który określa w jakiej części analizowanego przedziału czasu modem jest zajęty obsługą przychodzących wiadomości SMS. Z twierdzenia Changa-Lavenberga [11] wskaźnik aktywności i-tego modemu:

$$
U_{i}=\rho_{i}, \text { dla i }=1, \ldots ., \mathrm{M}
$$

We wcześniejszych pracach [9] zaprezentowano wyniki pomiarów, uzyskanych podczas badań opracowanego systemu informacyjnego, opartego na usłudze SMS. Ich celem było określenie czasu niezbędnego do obsługi określonej liczby wiadomości SMS przy wykorzystaniu standardowych modemów GSM. Wyniki pomiarów czasów wysiłki wiadomości SMS nie wykazały znaczących różnic ani 
Optimisation of the municipal waste collection process in a small size and...

Optymalizacja procesu odbioru odpadów komunalnych w gminie małej wielkości...

w zależności od ilości wiadomości SMS w jednorazowym pakiecie (wysyłanej porcji SMS), ani w zależności od wykorzystywanej sieci GSM. Jedynie w przypadku jednej sieci odnotowano zauważalny wzrost czasu wysyłki wiadomości SMS w zależności od liczby wiadomości SMS w pakiecie.

W sieci tej występowała także utrata kolejności w dostarczanych wiadomościach SMS (każda wiadomość SMS posiadała unikalny identyfikator), czego nie zaobserwowano podczas wysyłki w pozostałych sieciach. Nie zaobserwowano istotnych różnic także w odniesieniu do wykorzystywanego modemu GSM, ani wykorzystywanego oprogramowania. W pracy [8] zaprezentowano szczegółowa analizę oraz wyniki pomiarów i symulacji opracowanego w celu zwiększenia wydajności systemów informacyjnych modelu systemu teleinformatycznego, wykorzystującego komunikaty SMS. Wykazano, że zwiększenie gotowości takiego systemu jest możliwe dzięki równomiernemu obciążeniu każdego z modemów GSM. Pozwala to na dwukrotne zwiększenie liczby wiadomości SMS do przetworzenia, czyli przyczynia się do dwukrotnego wzrostu wydajności systemu informacyjnego.

\section{Eksploatacja pojazdów w systemie odbioru odpadów komunalnych na przykładzie małej gminy}

Dla potrzeb analizy wybrano gminę Paradyż, która jest gminą wiejską położoną w południowej części Niziny Mazowieckiej nad rzeką Czarną, w zlewni rzeki Pilicy, w południowo-wschodniej części województwa łódzkiego, w powiecie opoczyńskim. Zajmuje ona powierzchnię $81,4 \mathrm{~km}^{2}$, składa się z 27 sołectw i zamieszkiwana jest przez 4458 mieszkańców [12].

$\mathrm{Na}$ podstawie przeprowadzonego wywiadu środowiskowego oraz rozmów z władzami gminy Paradyż ustalono, że istnieje kilka problematycznych kwestii odbioru odpadów od mieszkańców. Jednym z problemów był odbiór odpadów w miejscowości Kłopotów. Część miejscowości znajduje się przy głównej drodze krajowej i łączy się z ulicą Piotrkowską w miejscowości Paradyż. Odbiór segregowanych odpadów odbywał się $\mathrm{w}$ miesiące nieparzyste, natomiast w Paradyżu w miesiące parzyste. Mieszkańcy wystawiali odpady miesiące parzyste i w nieparzyste, twierdząc że firma odbiera od nich odpady segregowane (Gmina Paradyż została podzielona na dwa regiony. Zmieszane odpady są odbierane raz w miesiącu w całej gminie, natomiast segregowane co drugi miesiąc). W związku $\mathrm{z}$ tym był problem zgłaszany przez mieszkańców czy odbiór w danym czy w przyszłym miesiącu. Mieszkańcy wystawiali odpady zarówno w jedne i jak drugie twierdząc, że firma odbiera od nich odpady segregowane, a dotyczyło to jedynie odpadów zmieszanych. $\mathrm{w}$ związku z tym problem był zgłaszany przez mieszkańców, czy odbiór odbywa się danym miesiącu czy kolejnym. 
Kolejnym problemem są nieruchomości w miejscowościach Adamów, Przyłęk, Solec, Stanisławów i Sylwerynów do których utrudniony jest dojazd ze względu na nieutwardzone powierzchnie dróg.

W związku z tym, odbiór odpadów z tych posesji musiał odbywać się pojazdem o mniejszej ładowności, co generowało dodatkowe koszty. Zakład Unieszkodliwiania Odpadów znajduje się w miejscowości Różana, odległej od Paradyża o ponad $20 \mathrm{~km}$. Niektórzy $\mathrm{z}$ właścicieli posesji zgłaszali również zapotrzebowanie na częstszy odbiór odpadów selektywnych niż co drugi miesiąc, jak ma to miejsce obecnie.

W celu usprawnienia całego procesu oraz uzyskania optymalnych parametrów wykorzystania środków transportu uczestniczących w procesie zaproponowanym rozwiązanie oparte o system powiadomień SMS. Za jego pomocą mieszkańcy zgłaszają zapotrzebowanie na usługę. W przypadku zebrania odpowiedniej ich liczby, program dostarcza zawiadomienie do firmy odpowiedzialnej za odbiór odpadów, która wysyła pojazd, dostosowany do odpowiedniej usługi (ze względu na ilość zgłoszeń lub powiadomienia od właścicieli nieruchomości, do których istnieje utrudniony dojazd). Innym zadaniem stworzonego systemu jest informowanie wszystkich mieszkańców z wyprzedzeniem o planowanym odbiorze zmieszanych i selektywnych odpadów z posesji.

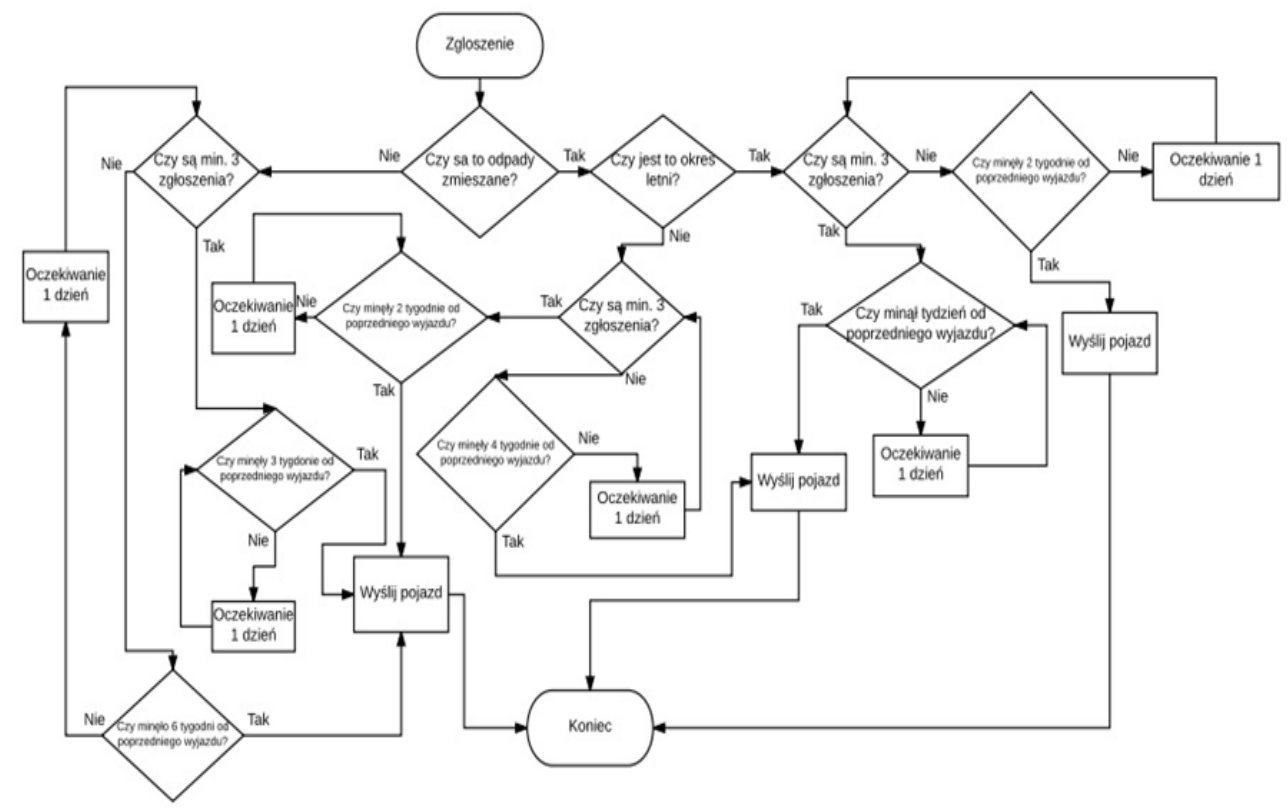

Rys. 3 Algorytm pracy systemu procesu odbioru odpadów [13] 
Optimisation of the municipal waste collection process in a small size and...

Optymalizacja procesu odbioru odpadów komunalnych w gminie małej wielkości...

Funkcjonowanie systemu odbioru odpadów przedstawiono za pomocą algorytmu. Ze względu na klimat i panujące w Polsce warunki atmosferyczne, rok kalendarzowy podzielony został na dwa okresy, gdzie zasadniczą różnicą pomiędzy okresami jest częstotliwość odbioru odpadów: okres letni (od 1 maja do 30 września) oraz okres zimowy (od 1 października do 30 kwietnia).

Po zapoznaniu z wymogami zbiórki odpadów oraz na potrzeby algorytmu, określono następujące kryteria ze względu na rodzaj odpadów, termin ich odbioru oraz opłacalność wyjazdu:

- odpady zmieszane: minimum 3 zgłoszenia; minimum 1 tydzień od poprzedniego wyjazdu $\mathrm{w}$ okresie letnim; maksimum 2 tygodnie od poprzedniego wyjazdu w okresie letnim; minimum 2 tygodnie od poprzedniego wyjazdu w okresie zimowym; maksimum 4 tygodnie od poprzedniego wyjazdu w okresie zimowym.

- odpady selektywne: minimum 3 zgłoszenia; minimum 3 tygodnie od poprzedniego wyjazdu; maksimum 6 tygodni od poprzedniego wyjazdu.

Oprogramowanie systemowe powiadamia $\mathrm{z}$ wyprzedzeniem wszystkich użytkowników systemu (mieszkańców) o planowanym wyjeździe pojazdu w celu odbioru odpadów. Kolejna zbiórka będzie możliwa po minimalnym czasie określonym w algorytmie dla danego typu zgłoszenia.

\section{Podsumowanie}

Opracowane rozwiązanie dedykowane jest z założenia małym gminom, gdzie ze względu na stosunkowo niewielką liczbę mieszkańców szczególne znaczenie ma planowanie i organizacja przewozów - odbioru odpadów. Problem ten nabiera jeszcze większego znaczenia na obszarach o małej gęstości zaludnienia, gdzie proporcjonalnie nieduża liczba punktów odbioru rozrzucona jest na stosunkowo dużym obszarze. Jest to główną przyczyną wzrostu kosztów przewozów, generowanych przez przejazdy $\mathrm{w}$ przy jedynie częściowym wykorzystaniu ładowności pojazdów. Przyczynia się to do znaczącego wzrostu kosztów eksploatacji utrzymywanej floty pojazdów. W sytuacji realizacji przewozów $\mathrm{w}$ ramach dedykowanej ustawy oraz umowy zawartej z samorządem regulujących częstotliwość i terminowość odbioru odpadu nie ma prostego mechanizmu gwarantującego redukcję kosztów do akceptowalnego poziomu.

Proponowane i przeanalizowane rozwiązanie wychodzi naprzeciw tym problemom i wydatnie przyczynia się do optymalizacji kosztów przewozu oraz wzrostu efektywności eksploatacji środków transportu. Opracowana i przetestowana aplikacja zwiększa gotowość całego systemu, rozumianą jako terminowość realizacji zadania przy minimalizacji kosztów eksploatacji. Jednocześnie możliwa jest skalowalność systemu i jego wdrożenie w warunkach znacznej odmienności demograficznej i obszarowej. 
Przy opracowaniu i wykorzystaniu w dalszych badaniach modelu symulacyjnego możliwe będzie wyznaczenie wskaźników niezawodnościowych, które pozwolą na opracowanie wytycznych umożliwiających wdrożenie opracowanego rozwiązania w praktyce.

\section{Artykul opracowano w zwiazku z realizacja projektu RID $4 D$ pt. „Wphyw stosowania ushg Inteligentnych Systemów Transportowych na poziom bezpieczeństwa ruchu drogowego", finansowanego przez Narodowe Centrum Badań i Rozwoju oraz Generalna Dyrekcję Dróg Krajowych i Autostrad (umowa nr DZP/RID-I-41/7/NCBR/2016).}

\section{Literatura}

[1] Encyklopedia Popularna PWN - wydanie szóste, Państwowe Wydawnictwo Naukowe, Warszawa 1982;

[2] Encyklopedia Powszechna PWN - tom 4, Wydawnictwo Naukowe PWN, Warszawa 1997;

[3] Ustawa z dnia 27 kwietnia 2007 r. Prawo ochrony środowiska [Dz. U. Nr 42, poz. 328.];

[4] Radecki W., Ustawa o odpadach, Wolters Kluwer Polska, Warszawa 2008;

[5] Narkiewicz J.: GPS i inne satelitarne systemy nawigacyjne, Wydawnictwo Komunikacji i Łączności, Warszawa 2007;

[6] Maciejewski M., Waleriańczyk W.: Porównanie systemów monitorowania i nawigacji dla floty pojazdów dostępnych na polskim rynku, VII konferencja naukowo-techniczna, Logistyka, Lidzbark Warmiński 2014;

[7] Product catalogue, http://www.activexperts.com/sms-messaging-server/, grudzień 2017;

[8] Rychlicki M., Kasprzyk Z.: Increasing Performance of SMS Based Information Systems, Advances in Intelligent Systems and Computing, vol. 286, 2014, Springer International Publishing, ISBN 978-3-319-07012-4;

[9] Rychlicki M., Kasprzyk Z., Integracja usług poczty elektronicznej oraz sms w małych i średnich przedsiębiorstwach transportowych, Zeszyty Naukowe Politechniki Warszawskiej, Seria Transport, z. nr 92, 1230-9265, Oficyna Wydawnicza Politechniki Warszawskiej 2013,

[10] Czachórski T., Modele kolejkowe systemów komputerowych, Politechnika Śląska, Gliwice 1999 ,

[11] Filipowicz B., Modele stochastyczne w badaniach operacyjnych - analiza i synteza systemów obsługi i sieci kolejkowych, WNT, Warszawa 1996. 
Optimisation of the municipal waste collection process in a small size and...

Optymalizacja procesu odbioru odpadów komunalnych w gminie małej wielkości...

[12] Główny Urząd Statystyczny: Ludność w gminach według stanu w dniu 31.12.2011 r. Bilans opracowany w oparciu o wyniki Narodowego Spisu Powszechnego 2011; dostępny na stronie: http://demografia.stat.gov.pl

[13] Jaśkiewicz K.: Projekt systemu monitorowania pojazdów i odbioru odpadów na przykładzie małej gminy, praca dyplomowa inżynierska, WT PW, Warszawa 2017;

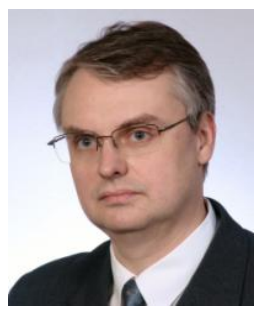

Mariusz Rychlicki, dr ini., Adiunkt, Zaktad Telekomunikacji w Transporcie, Wydziat Transportu Politechniki Warszawskiej. Zainteresowania naukowe: modelowanie systemów telematyki, analiza systemów lokalizacji $i$ monitoringu pojazdów, niezawodność systemów $i$ sieci teleinformatycznych. Autor kilkudziesięciu publikacji naukowo-technicznych (Udział 30\%).

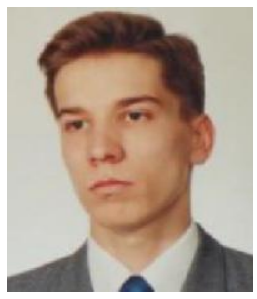

Zbigniew Kasprzyk, dr ini., Adiunkt, Zakład Telekomunikacji w Transporcie, Wydziat Transportu Politechniki Warszawskiej. Zainteresowania naukowe: modelowanie systemów poboru opłat $w$ transporcie, modelowanie funkcji telematyki transportu, analiza systemów operacyjnych, analiza niezawodności sieci transmisji danych. . Autor kilkudziesięciu publikacji naukowotechnicznych (Udziat 30\%).

Konrad Jaśkiewicz, inż, Absolwent Wydziat Transportu Politechniki Warszawskiej. Zainteresowania zawodowe: Telematyka transportu, systemy lokalizacji $i$ monitorowania pojazdów, eksploatacja pojazdów $w$ transporcie drogowym (Udziat 40\%). 